\title{
Search for system solutions for the development of parking space in the residential area of the Maykop urban agglomeration
}

\author{
Inna Akhunova ${ }^{1}{ }^{*}$, Larisa Tlekhurai-Berzegova ${ }^{1}$, and Galina Guk ${ }^{1}$ \\ ${ }^{1}$ Maykop State Technological University, Maykop, Adygea, Russia \\ ${ }^{2}$ Adyghe State University, Maykop, Adygea, Russia
}

\begin{abstract}
The growing number of personal cars in cities has given rise to the problem of congestion of city streets and roads, and as a result, a lack of parking spaces in the courtyards and adjoining territories of the existing residential development. One of the factors of chaotic parking of vehicles on the carriageway of the road network is the loading of courtyard and adjoining territories. As a result of the research carried out in this article, the authors propose system solutions for the development of parking space in the residential area of the urban agglomeration.
\end{abstract}

\section{Introduction}

The development of a modern city is associated with the accelerated pace of motorization, entailing an increase in the number of cars, and affecting all aspects of human life: safety, health, service, rest, work. The increase in the number of vehicles for personal use of citizens in cities is not only a problem of traffic safety for all its participants, but also characterized by an insufficient number of parking spaces for vehicles. The number of vehicles in urban areas is growing rapidly, and the development of transport infrastructure is lagging behind. Because of this, there is a problem of insufficient number of parking spaces, both closed storage (organized parking), and in an open area, in the courtyards of residential multi-storey buildings. Thus, parking "near the road", in the zone of green spaces and in playgrounds became the implementation of new "rules" for many city dwellers, and led to chaotically parked cars on the road network, which complicates transport and pedestrian traffic, increases the delay of vehicles, creates a conflict traffic situation. Today, the construction of new residential complexes makes it possible to diversify organizational and planning solutions in terms of the construction of parking lots of various configurations, and can act as a solution to the problem of providing most residents with a parking space for their car. However, construction Today, the construction of new residential complexes makes it possible to diversify organizational and planning solutions in terms of the construction of parking lots of various configurations, and can act as a solution to the problem of providing most residents with a parking space for their car. However, construction new residential complexes with built-in parking will not completely solve the existing problem, since today the old housing

* Corresponding author: inna0116@mail.ru 
stock is not adequately equipped with parking spaces due to the lack of territory for this. Thus, the search for solutions for the development of parking space to create the required number of parking spaces in modern conditions is an important task.

The purpose of the study is to find system solutions to reduce the traffic load on the road network of the city of Maikop and to partially unload the courtyard areas.through the development of parking space.

\section{Main part}

The development of transport as one of the main elements of the city, meeting the travel needs of its population, is the object of close attention of the city authorities. On the one hand, the transport system of any city is the source of life for the population, meeting the demand for transport services. On the other hand, with the increase in traffic, a conflict has arisen between the existing traffic and the capacity of the road network. Unjustified parking of cars, and even more so the lack of parking spaces, has a negative impact on the organization of the movement of pedestrians and vehicles. According to the author [1], "parking, an integral part of the transport system, is a serious problem faced by urban planners and traffic specialists."

The problem of parking is acute not only in Russia, but all over the world. Xiao H., a scientist at Beijing University of Technology, China, draws attention to the backward development of parking complexes, and notes "these problems seriously affect travel, traffic and the quality of life in urban areas, as the problem of parking has become very important and influenced sustainable urban development." [2].

Fundamental decisions on the organization and management of car parks should be made at the federal, regional and municipal levels, taking into account the experience of foreign countries. For example, in France, the solution to the problems of management of parking services goes to the state level [3]. In Austria, when organizing parking in cities, improved parking rules have been proposed [4].

The growth of vehicles in urban areas in the last decade has created a problem of traffic congestion on the roads and led to the paralysis of the existing parking space. The level of motorization in Russia as a whole as of January 1, 2020 amounted to 303 passenger cars per 1000 people. This indicator is different in the cities of Russia, for example, in the city of Tomsk with a population of 576 thousand people. [5], the level of motorization reached 276 cars per 1000 inhabitants. And at this level of motorization, "the standardized areas in residential buildings are not enough for the required number of cars" [6].

The city of Maykop is small in terms of the number of 141.5 thousand people and population density, has a rectangular layout of the road network [7]. The level of motorization of the urban agglomeration reaches 530 cars per 1000 inhabitants. The road transport infrastructure was founded in the middle of the last century, when, objectively, there were completely different conditions for road traffic. The development of a system of organized parking lots, areas and places for car storage is significantly lower than the growth rate of the car park.

We have repeatedly raised the issue of the problem of organizing storage places for personal vehicles, arranging parking lots and organizing the movement of vehicles and pedestrians in the city of Maykop. It is noted that "in the absence of a solution to these problems, cars are parked on the carriageway of the city streets during the daytime, reducing the already limited throughput "[8]. The measures taken by the municipality to develop car parks with a significant annual increase in vehicles are insufficient. This problem is especially acute in the central, southeastern and western parts of the city during rush hours [9].

The rapid processes of motorization in cities have led to the spontaneous use of courtyard areas for parking vehicles. As for many Russian cities, in the city of Maikop there is an acute problem of storing individual motor transport, especially in its central and "sleeping" 
neighborhoods. Due to the lack of area of courtyard areas of residential development, vehicles are left on the sides of the carriageway of the road network, thereby hindering the movement of traffic. Yard areas of residential buildings (lawns, playgrounds, green areas, driveways) have turned into a car park, posing a threat to the safety of residents, deteriorating the ecological situation and disrupting the aesthetic appearance of the living environment [10].

The ongoing process of motorization worsens the ecological situation in Maikop, and over time, the ecologically clean "green" city and its inhabitants are exposed to the danger of negative impact on the environment, air and soil pollution. Only for the period 2016-2020. the fleet of passenger cars in our city has increased by almost 12,000 units (an average increase of about 2,000 vehicles per year), which require their placement.

And of course, the method of storing vehicles in Maikop is mainly storing cars in a free open area, or in the courtyards of multi-storey buildings. Residents of apartment buildings park their cars, as a rule, along the roadway, in courtyards, often in green areas, as well as under the windows of apartments on the first floors. An analysis of the organization of parking lots in most city courtyards showed that chaotically parked cars interfere with the passage of special vehicles: ambulances, fire and communal services, private security.

There is no construction of multi-storey overground parking lots, there are practically no semi-underground and underground parking garages (in the city there are only 3 objects of these types: in residential buildings on Gaidar St., Dimitrova / Kurgannaya St. and Sovetskaya St.).

Assessing the situation in the field of organizing car parking in Maikop, the following should be noted: in the overwhelming majority of the objects of parking and temporary storage of cars in the urban area are the Central Market area, near universities, government institutions, as well as shopping and entertainment centers. There are much fewer parking lots in the Cheryomushki residential area (according to the results of the study, 3 parking lots), where a greater number of developments in residential complexes are concentrated.

Observations on the organization of parking lots were carried out in the courtyards of residential buildings in the city of Maikop: residential complex "Chkalovsky" (Cheryomushki district); Lenin street, st. Pushkin (Gorpark area); st.Pervomaiskaya, st.Proletarskaya, st. March 8 (central area of the city); st. Dimitrov, st. Deputy (area of the Turkish Bank); street Korotkaya, st.Zavodskaya (Shovgenovskytown).

Parking of cars is possible in the inner courtyard area, limited by residential buildings, and along the outer contour of residential buildings. Playgrounds and green areas, pedestrian paths often become a parking zone in courtyards. This led to the inconvenience and discomfort of residents, a decrease in the safety of life and health when children go out for a walk, as well as the aesthetic appearance deteriorates and the ecology of the courtyards is disturbed (Fig. 1, 2).
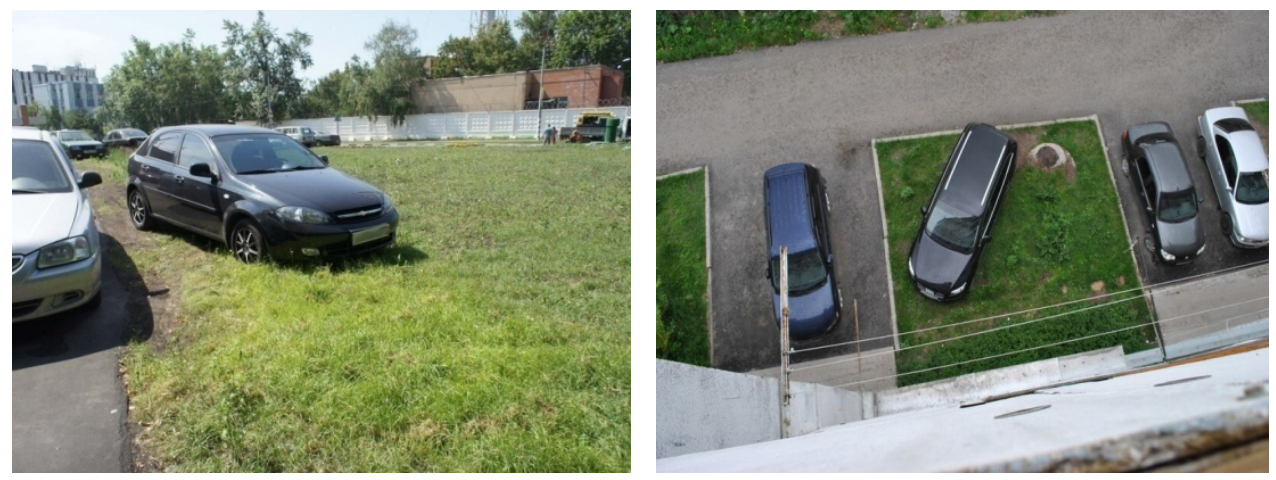

Fig. 1. Parking cars on lawns. 
In the courtyards, the grass cover is destroyed, the shrubs have a withering appearance, as a result, soil degradation occurs. The location of cars near the entrances to the entrance of residential buildings can impede the passage of ambulances to the sick, workers of communal services and fire services (Fig. 3).

As a result of the analysis of the survey of the courtyard areas of multi-storey residential complexes, a number of problems were identified related to the parking of vehicles inside and near the courtyard areas of residential buildings:

- reducing the safety of citizens;

- a decrease in the level of improvement of the courtyard territory and the conditions of comfort for people in places of residence and recreation;

- congestion of yards with cars and, as a result, the lack of the possibility of emergency passage of special vehicles in the yard area (ambulance, utility vehicles);

- environmental pollution, negative impact on public health;

- wear and tear of the pedestrian zone, destruction of the landscape and vegetation cover in the yards;

- a decrease in the throughput of city streets due to parked cars on the roadway near multistorey residential buildings.
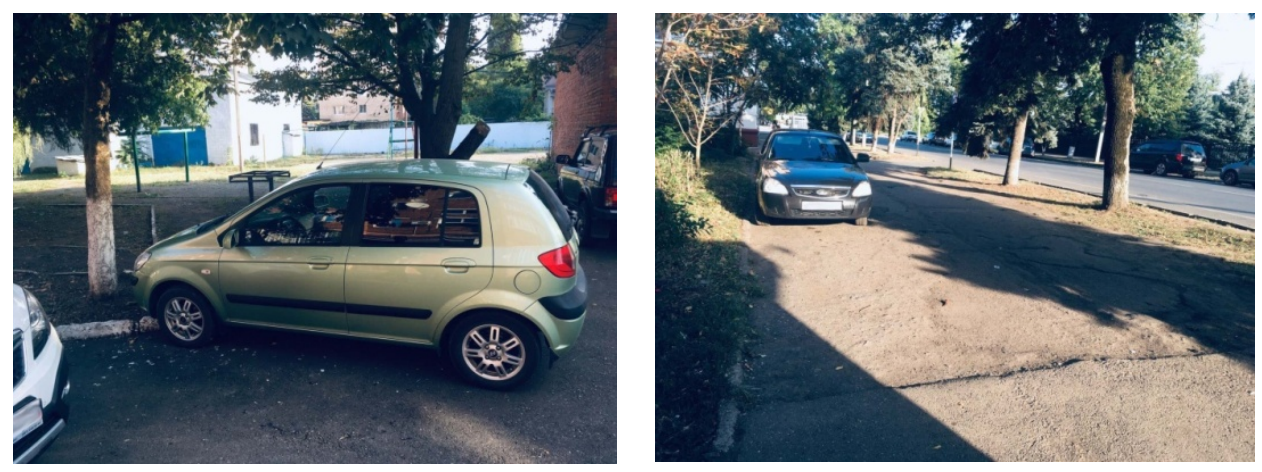

Fig. 2. Parking cars on sidewalks and walkways.
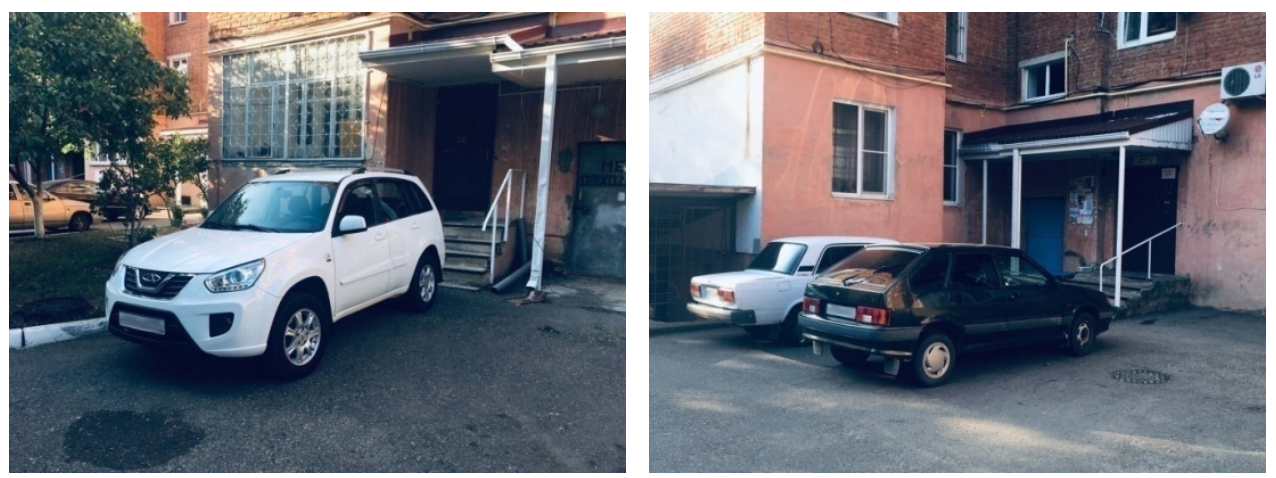

Fig. 3. Car parking near the entrances and entrances to residential buildings.

Therefore, from the point of view of long-term and short-term development, solutions are needed to improve the city's road transport infrastructure, the quality of life of people, the state of the environment, and improve road safety. The following ways are possible to reduce the traffic load of the road network, to solve the problem of improving the road infrastructure and traffic safety for all participants on the territory of the Maikop agglomeration: 
1. Strategic (at the state level):

- all projects for the construction of new multi-storey buildings must have equipped parking spaces, determined by the level of provision of the population with individual light vehicles.

- the most effective way to solve the problem of organizing car parking near existing residential buildings is to use free urban areas for parking space.

2. Tactical:

- to increase the number of parking spaces, the organization of a centralized system of car parking by the type of multi-level ground parking in the existing car parks of the city territory.

- compulsory control of precinct commissioners for cars that are not in parking spaces (green area, playground);

- automatic parking systems with information support through a mobile application, equipped with intelligent devices that indicate the availability of free spaces [11];

- arrangement of existing adjoining territories with mechanized parking lots.

The existing problems with the parking of cars in our city have arisen due to the fact that most of the housing stock with the existing adjoining territories was built in Soviet times at the rate of 5-10 cars per house. This follows from the regulatory document regarding the organization of open parking lots for temporary storage of cars in residential areas at the rate of $25 \%$ of the existing fleet of individual cars [12].

In modern urban planning conditions, the number of parking spaces is regulated by the Code of Rules [13] based on the type of residential building in terms of comfort level (Table 11.8), which means the number of parking spaces is tied to the number of apartments. And in the regulatory framework [14], the design conditions, location of parking lots (storage) of cars are indicated. The above documents, namely in terms of the construction of multi-storey residential complexes, do not reflect the conditions for organizing car parks, taking into account the level of motorization in the region. On the basis of [15] "Substantiation of the calculated indicators of the provision of objects with car parks" in the city of Maikop, places for storing cars are provided based on the level of motorization for 250 - 290 cars per 1000 inhabitants.

Thus, during the construction of new residential buildings (complexes), the conditions specified in SP 42.13330.2016 must be the minimum requirements for the developer. An obligatory requirement when determining the number of parking spaces for each multi-storey building in a residential complex, we suggest taking into account the level of motorization in a given city, if it exceeds that given in the regulatory documents.

We believe that in order to solve the problem of freeing the carriageway of the road network from standing cars, it is necessary to create an effective parking system on the scale of a residential building, a given microdistrict, a city. This system shouldbe based on:

- statistical data on parked vehicles in the residential area and on the roadway of the UDS;

- calculation of the number of required parking spaces in courtyards, taking into account the level of motorization in the city;

- creation of models for the location of parking spaces for cars in the courtyard area.

\section{Conclusion}

The continuing growth of passenger cars on the territory of the Maykop urban agglomeration has gradually led to an increase in the degree of utilization of residential yards, creating a large traffic load on the road network of adjacent adjoining territories. The inconsistency between the growth in the number of vehicles for individual use and the development of road infrastructure in the future may lead to the localization of the problem of reduced throughput at each section of the road network. The proposed solution to the problem of reducing the 
traffic load of city streets and roads is to develop parking space taking into account the level of motorization in the city.

\section{References}

1. Joseph O. Oyedepo. Performance. Analysis of Off-Street Parking around the Central Business District of Akure Southwest Nigeria. The Journal of Sustainable Development. (2016), Vol. 16, Iss. 1, Pp. 91-105. https://core.ac.uk/download/pdf/161456331.pdf

2. X. Xiao A study of the motor vehicle parking management in China's major cities. LISS 2012 Proceedings of 2nd International Conference on Logistics, Informatics and Service Science, (2013), pp 1451-1456. https://link.springer.com/chapter/10.1007/9783-642-32054-5_205

3. Le Squeren Z. Plural Governance for the Management of Local Public Services: An Empirical Investigation on the French Car Park Industry. Management, (2020), pp 2843. DOI: 10.37725 / mgmt.v23i4.4738.

4. T. Brezina, J.M. Schopf From Regional Austrian Parking Ordinances to Sound Guidelines. Engineering tools and solutions for sustainable transportation planning, (2017), pp 177-203. DOI: 10.4018 / 978-1-5225-2116-7.ch008.

5. https://ru.wikipedia.org/wiki/Tomsk

6. M.V. Kamynina The influence of motorization in large cities in Russia on the formation of the urban environment. Electronic scientific journal "Naukosphere", (2019), No. 5. from. 10-12.

7. https://geogoroda.ru/gorod/maykop-rossiya

8. I.B. Akhunova, A.Z. Udzhukhu, G.A. Guk Elements of intelligent transport systems in the functioning of the transport and road complex of small towns. Transport Information Bulletin, (2018), No. 10 (280), p. 29-32. http://www.natrans.ru/arttext.asp?artnum $=2236$.

9. I.B. Akhunova, G.A. Guk The problem of car parking in cities. Problems of the quality and operation of vehicles: materials of the XIII Intern. correspondence scientific and technical conf. - Penza: PGUAS, (2017).p.16-20.

10. I.B. Akhunova, M.V. Prelikov On the issue of the need for a new system for organizing in-yard car parking. NEW SCIENCE. Collection of scientific works based on the materials of the scientific and practical conference, (2018), p. 18-20.

11. A. Hilmani, A. Maizate, L. Hassouni Designing and Managing a Smart Parking System Using Wireless Sensor Networks. Journal of sensor and actuator networks, (2018). DOI: 10.3390 / jsan7020024.

12. SNiP 2.07.01-89* "Urban planning. Planning and development of urban and rural settlements. "

13. SP 42.13330.2016 "Urban planning. Planning and development of urban and rural settlements. Updated edition of SNiP 2.07.01-89*".

14. SP 113.13330.2016 "Parking lots. Updated edition of SNiP 21-02-99 * ".

15. Appendix to the Decision of the Council of People's Deputies of the municipal formation "City of Maykop" dated October 26, (2017) N 279-rs "Local standards of urban planning of the municipal formation" City of Maykop" https://docs.cntd.ru/document/446574947. 